\title{
Synthesis of zeolites and their applications as lon exchange to remove water hardness
}

\author{
Mohammed ElTayeb Abd ElKarim and Saif Alnasr Abd Elmajed Said Ahmed
}

\author{
Ministry of Water Resources and Electricity Email: \\ aboeltayeba@yahoo.com \\ University of Al-Neelain-Department of Chemistry Email: \\ Safco006@yahoo.com
}

\begin{abstract}
In this study fifteen types of natural zeolites and synthetic zeolites and clay (Bentonite, Kaolinte) were used. Nine types of synthetic zeolites (K-fledspar, clay and trona) were synthesized by using local crude materials, also the column that was used for treating hard water was prepared from natural zeolite, synthetic zeolite and clay. The sample of red sea water was collected from segala areaat eastern side the of Port Sudan city. The study was investigated to determine the concentration of metals that causes hardness $(\mathrm{Ca}, \mathrm{Mg})$. The location of samples was taken from segala area at eastern shore of Red Sea of Port Sudan this area is the main source for Red sea water to the desalination plant, which supplies the city with drinking water. The analysis was investigated to determine the other parameters of water. Hydrogen ion concentration $\mathrm{pH}$ was measured using $\mathrm{pH}$ meter, TDS concentration was determined by TDS meter. So the concentration of cation metals especially those who caused water hardness $(\mathrm{Ca}, \mathrm{Mg})$ were determined by using titration by E.D.T.A and other solutions. They synthetic zeolite, natural zeolite and clay which used in this study were identified a long with XRD and IR.Mainly, this study was concentrated on treatment of metals which causes water hardness $(\mathrm{Ca}, \mathrm{Mg})$. The treatment process for synthetic zeolite and natural zeolite were recorded and all analysis results of elements in this study were analyzed, and the synthetic and natural zeolite was found to be better than clay and Albite was found to be the best type in this study .

Key words : Hardness, zeolite, white kaoline, red kaoline, Total Dissolved Salts.
\end{abstract}

\section{INTRODUCTION}

Drinking water quality has always been a major issue in many countries, especially in developing countries (Assembly of Life Sciences, 1977). Safe drinking water is a human birthright - as much a birthright as clean air. As a matter of fact, in most of the African and Asian countries, even in relatively advanced countries such as India; safe drinking water is not easily available (TWAS, 2002). In some regions, it has been shown that investments in water supply and sanitation can yield a net economic benefit, since the reductions in adverse health effects and health care costs outweigh the costs of undertaking the interventions (WHO,2008).

Calcium: Calcium is the third element in group 1 IA off the periodic table called the alkaline earth metals (Nebergall et al., 1976), it has an atomic number of 20 an atomic weight of 40.08, an a valence of 2 . Calcium contributes to the total hardness of water.

Sources of calcium .The average abundance of $\mathrm{Ca}$ in the earth's crust is $4.9 \%$ and in ground waters it's form 1 to $>500 \mathrm{mg} / \mathrm{L}$. the most common forms of $\mathrm{Ca}$ are $\mathrm{CaCO} 3$ (calcite) and $\mathrm{Ca}-\mathrm{Mg}$ carbonate (dolomite), other natural forms of calcium carbonate include: aragonite, chalk, marl, etc ... (Nebergall et al., 1976).

\section{Magnesium:}

Properties and Uses Magnesium: Magnesium is a silvery- white metal which is malleable and ductile at high temperature. Although it's very active, magnesium is not readily attacked by air or by water, due to the formation of a protective basic carbonate film on its surface. Magnesium will unite with most non metals. (Bibudhendra !fiarkar,2002).

Zeolites are microporous,crystalline aluminosilicates consisting of three components: framework tetrahedra, cations, and adsorbed molecules.

zeolites can be, approximately, divided into alkaline earth and calcic ones. In general, the calcic zeolites are found in higher temperature environments than the alkaline earth forms (Velde ,1995). 
Classification: Zeolites and zeolite related materials are classified according to their framework structure, in addition to their chemical composition that can usually be considered variable. Each framework type can be described by their secondary building units, framework density, channel system, crystal symmetry and unit cell constant (Nagy et al. 1998).

Applications of Zeolites: Zeolites have numerous applications. Some of the most important applications are in catalysis, gas adsorption, industrial gas separation, water treatment (wastewater and drinking water), agriculture, and metal immobilization in soils (Flanigen, 1980).

Ion exchange in zeolites: The simplest case in any ion exchange system consists of three phases, namely the exchanger, external solution and vapour; however for most systems vapour can be ignored. lon exchange is a stoichiometric reaction. There are a various materials used as ion exchangers, including organic based resins, zeolites, AIPO4-n S (including the SAPOs) and double-layered metal hydroxides(Sheppard and Arthur, 1982).

\section{MATERIALS and METHODS}

\section{Materials}

Sample Sources: Natural zeolites were collected from Doka Elglabat and Sahra Bayoda, the clays were collected from western Omdurman and the synthetic zeolite was prepared in Lab.

The water samples were collected from Red Sea from the shore of port Sudan City Segal area.

\section{Methods:}

Preparation of zeolite plus Mg: Magnesium chloride was added to k-feldspar, clay, trona, and the mixture was crushed by mortar and was puted in ceramic crucibles in high temperature in furnace and the furnace was controlled to 1100 for 6 hours. The prepared samples were stored in adesicator.

Preparation of Zeolite plus Red kaoline: Kfeldspar, clay and trona were added to red kaoline and crushed by mortar till to be apowder and the mixture was put in furnace 1100 for 6 hrs then stored in adescicator.

\section{Preparation of natural zeolites:}

Natural zeolites were ground to powder by mortar and the powder was washed by di ionized water and puted in the often for $2 \mathrm{hrs}$ after that apowder was stored in adesicator.

Sample Processing: A Small column techniques was designed as a unit and the raw material of Zeolite was packed in the column and the water which contains hardness and traces of heavy metals and other salts was passed through the column.

\section{RESULTS and DISCUSSION}

General Results of cations and TDS: The results of the general tests of $\mathrm{Ca}, \mathrm{Mg}$ and TDS are shown in tables from 1-3.

All results were taken in ppm units

Table. 1 result of Calcium

\begin{tabular}{|l|c|c|c|c|c|c|c|c|}
\hline Test & Raw & N.Z (1) & N.Z (2) & N.Z (3) & N.Z (4) & $\begin{array}{c}\text { Red } \\
\text { kaolin }\end{array}$ & W kaolin & Zy \\
\hline Ca++ & 1296 & 520 & 1480 & 1120 & 1320 & 522 & 3160 & 542 \\
\hline Test & Z+Li & Z+Na & $\begin{array}{c}\text { Red } \\
\text { kaolin }\end{array}$ & W kaolin & Z+ Mg & Z+Cu & Bentonite & Kaoline \\
\hline Ca++ & 560 & 960 & 232 & 3360 & 560 & 920 & 560 & 520 \\
\hline
\end{tabular}

Over all analysis of TDS and hardness the best synthetic zeolite which decreased the TDS and hardness is the zeolite and red kaoline which decreased the TDS from $42840 \mathrm{ppm}$ to $1444 \mathrm{ppm}$ and the calcium from $1268 \mathrm{ppm}$ to 232ppm and magnesium from $8584 \mathrm{ppm}$ to $388 \mathrm{ppm}$ and in this process we used $125 \mathrm{~g}$ of S/zeolite to $1000 \mathrm{ml}$ of water sample. 
Table. 2 Result of Magnesium

\begin{tabular}{|l|l|l|l|l|l|l|l|l|}
\hline Test & Raw & N.Z (1) & N.Z (2) & N.Z (3) & N.Z (4) & $\begin{array}{l}\text { Red } \\
\text { kaolin }\end{array}$ & W kaolin & Zy \\
\hline Mg++ & 8584 & 7780 & 8500 & 8586 & 5780 & 1190 & 9040 & 6658 \\
\hline Test & Z+Li & Z+Na & Z+Mg & $\begin{array}{l}\text { Z+ Red } \\
\text { kaolin }\end{array}$ & $\begin{array}{l}\text { Z+ } \\
\text { wkaolin }\end{array}$ & Z+Cu & Bentonite & Kaolin \\
\hline Mg++ & 840 & 5540 & 1140 & 398 & 9040 & 2480 & 8260 & 1180 \\
\hline
\end{tabular}

Also, it is clear that the concentration of $\mathrm{Mg}$ ions were very high and the S.zeolites was removed these ions and the S.zeolties is better than natural zeolite in treatment S.zeolites is better than natural zeolite in treatment process although the weight of natural zeolites which were used in treatment process was double S.zeolite.

Table.3 result of Total Dissolved Salts

\begin{tabular}{|l|l|l|l|l|l|l|l|l|}
\hline Test & Raw & N.2(1) & N.Z(2) & N.Z(3) & N.Z(4) & $\begin{array}{l}\text { Red } \\
\text { Kaol }\end{array}$ & W Kaol & Zy \\
\hline T.D.S & 42840 & 45430 & 30740 & 29820 & 44030 & 24402 & 27580 & 33600 \\
\hline Test & Z+Na & Z+Li & Z+Mg & Red Kaol & W Kaol & Z+Cu & Bentonite & Kaoline \\
\hline T.D.S & 27930 & 27930 & 21420 & 14900 & 27720 & 28070 & 24360 & 24430 \\
\hline
\end{tabular}

The TDS of red sea water sample is about 42840 ppm is generally high within the range bettern 1000 -
15000 ppm due to high evaporation, low precipitation, and the lack of a major river inflow. 
Am. J. Sci. Ind. Res., 2013, 4(3): 317-327

Figures of IR of Zeolites :

The figures of IR of Zeolites results are shown in figure from 1-3

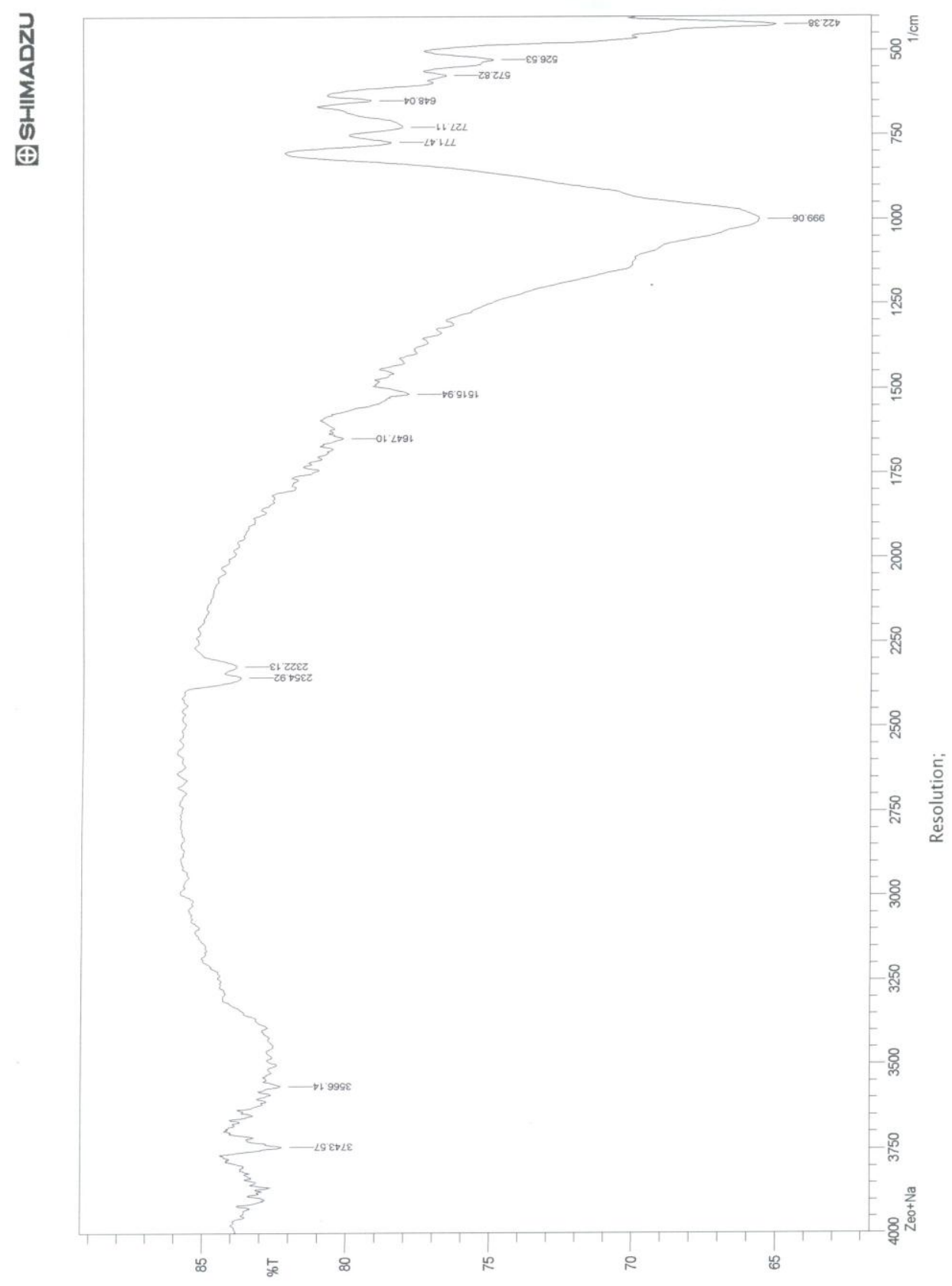

Fig .1 IR of S.Zeolite (4) 
Am. J. Sci. Ind. Res., 2013, 4(3): 317-327

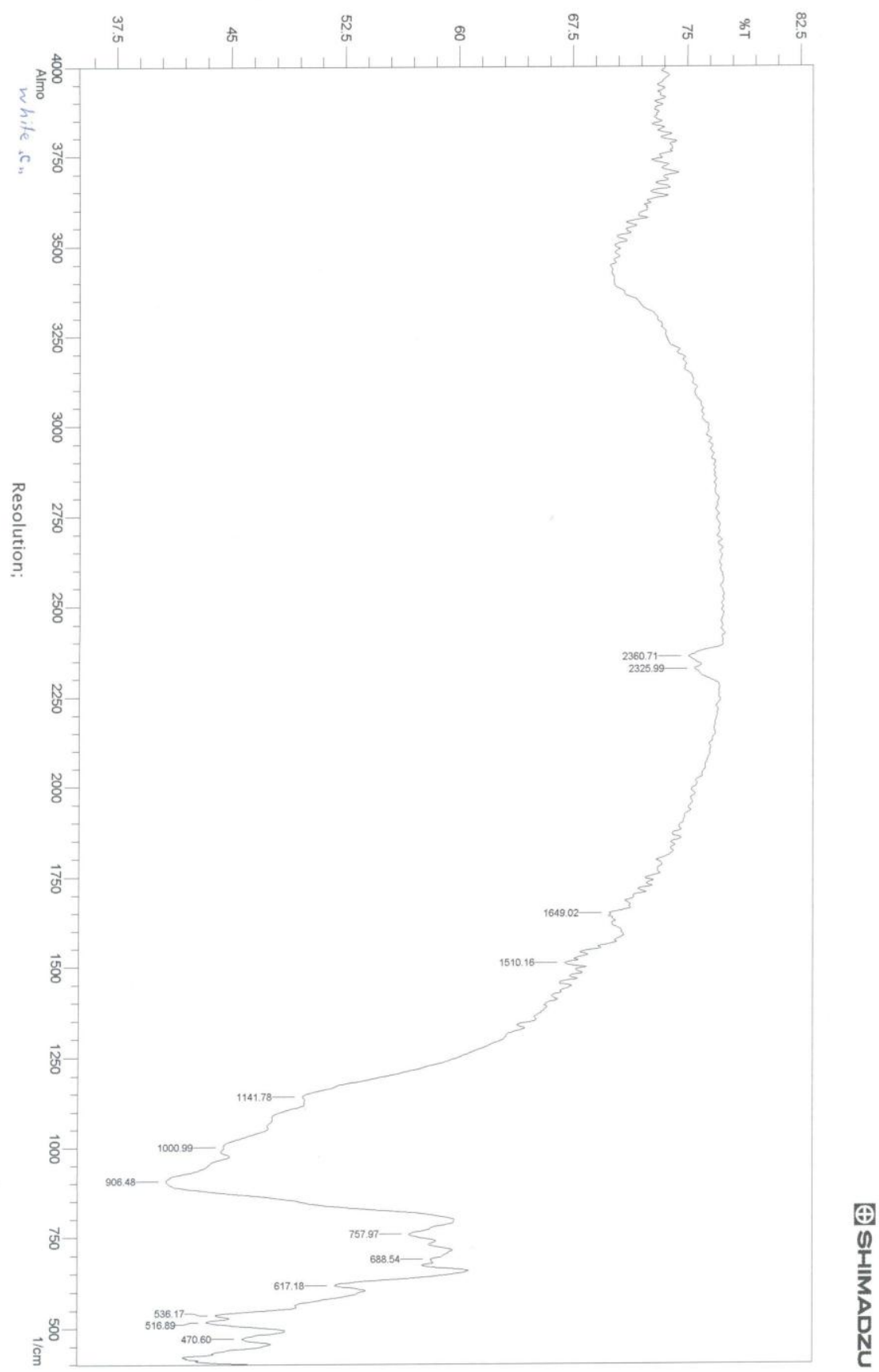

Fig .2 IR of S.Zeolite (5) 
Am. J. Sci. Ind. Res., 2013, 4(3): 317-327

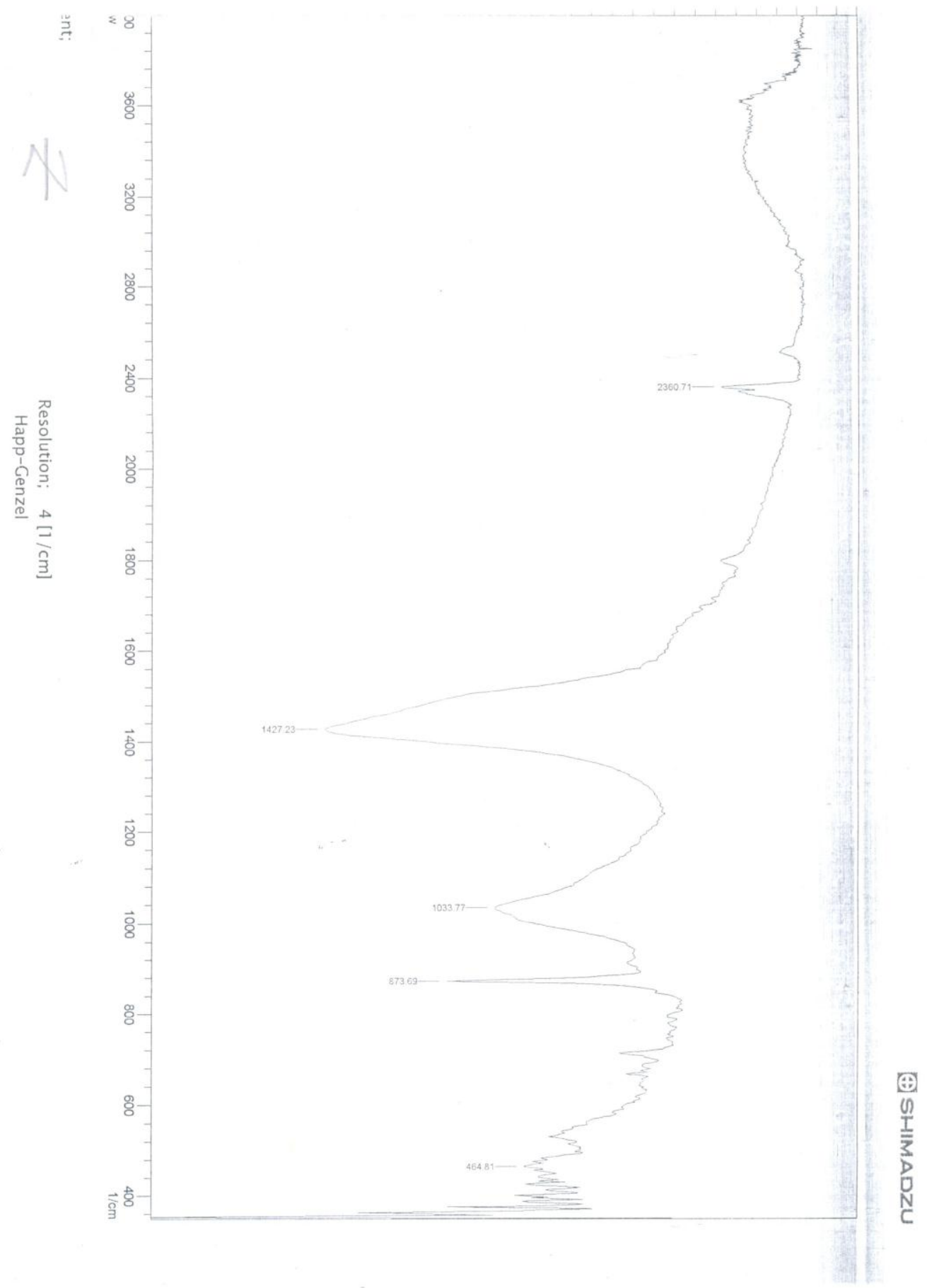

Fig.3 IR of S.Zeolite(4). 
Am. J. Sci. Ind. Res., 2013, 4(3): 317-327

\section{Figures of XRD of Zeolites :}

The results of XRD OF Zeolites were show in figures from 4_6

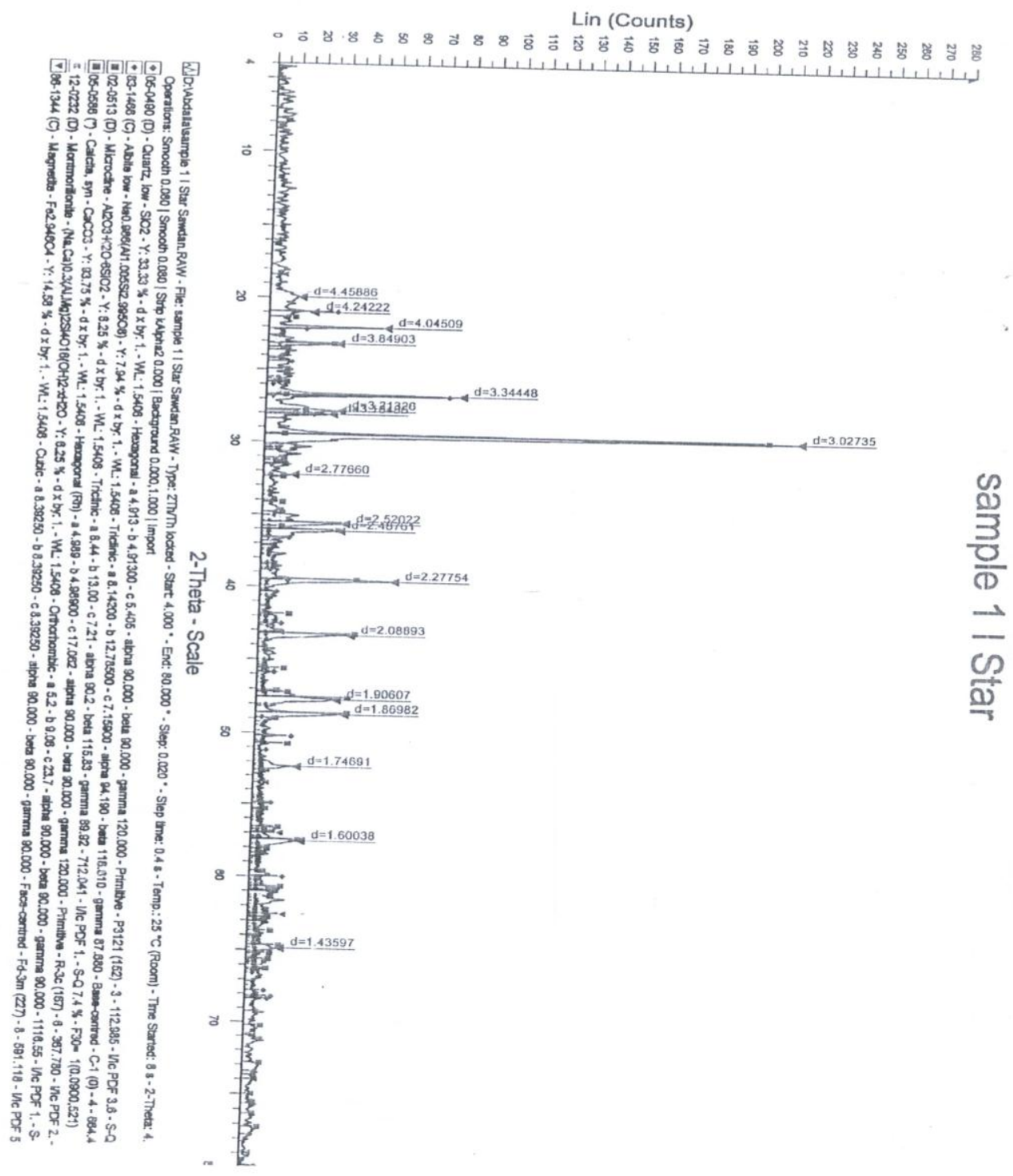

Fig .4 XRD of S.Zeolite 
Am. J. Sci. Ind. Res., 2013, 4(3): 317-327

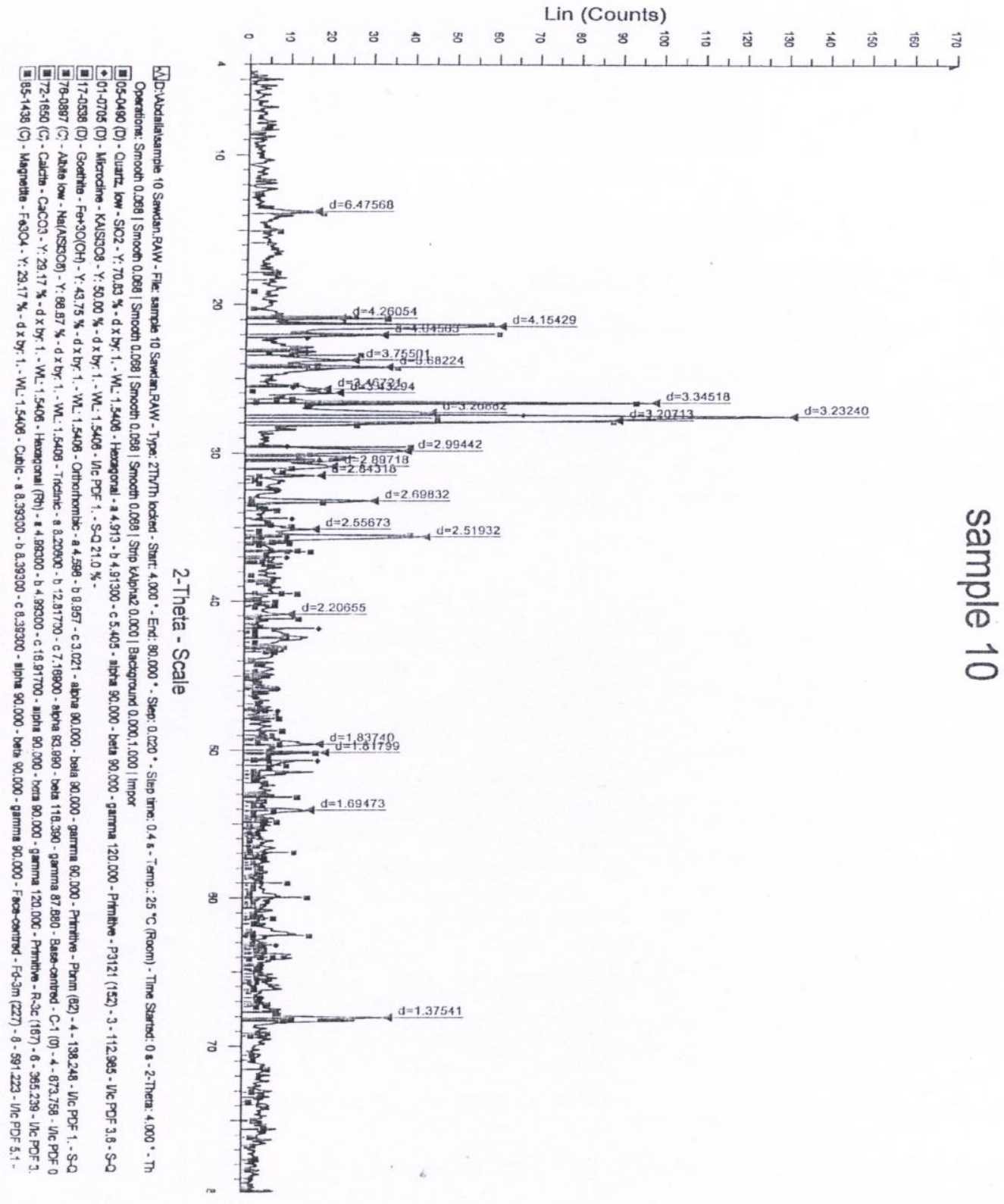

Fig 5 XRD of S.Zeolite . 
Am. J. Sci. Ind. Res., 2013, 4(3): 317-327

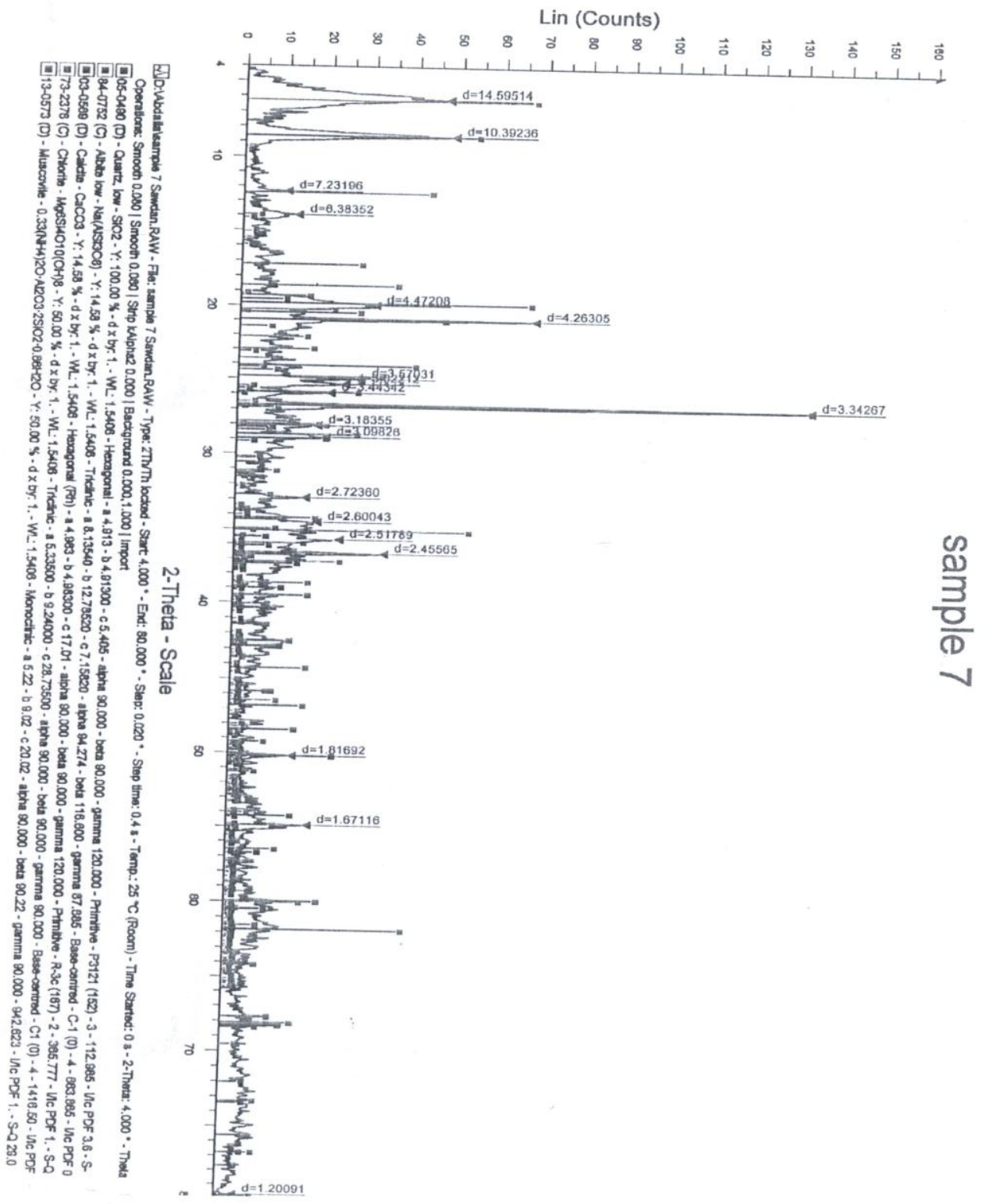

Fig 6 XRD of S.Zeolite. 


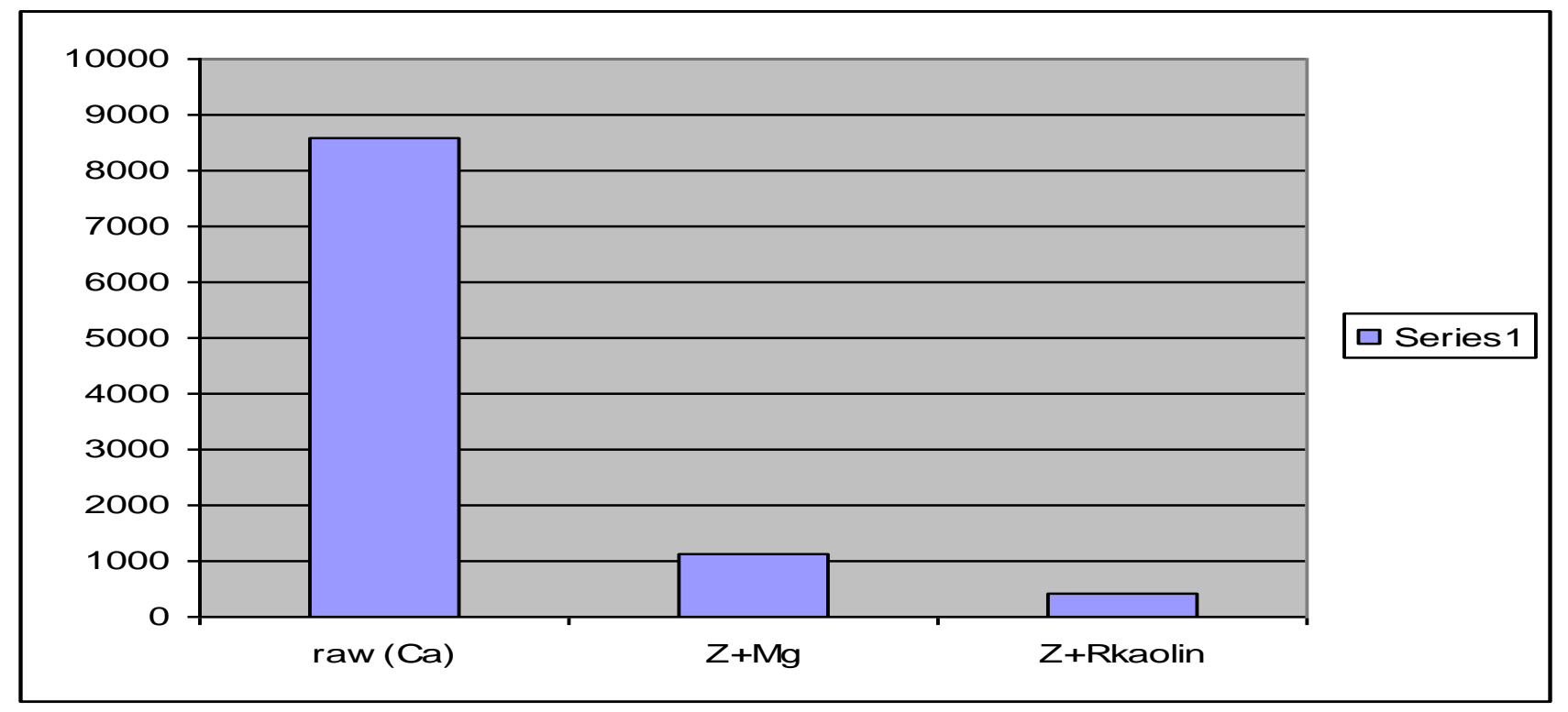

Fig 7 Comparison between Zeolite plus Red Caoline and Zeolite plus Mg for removal of Calcium

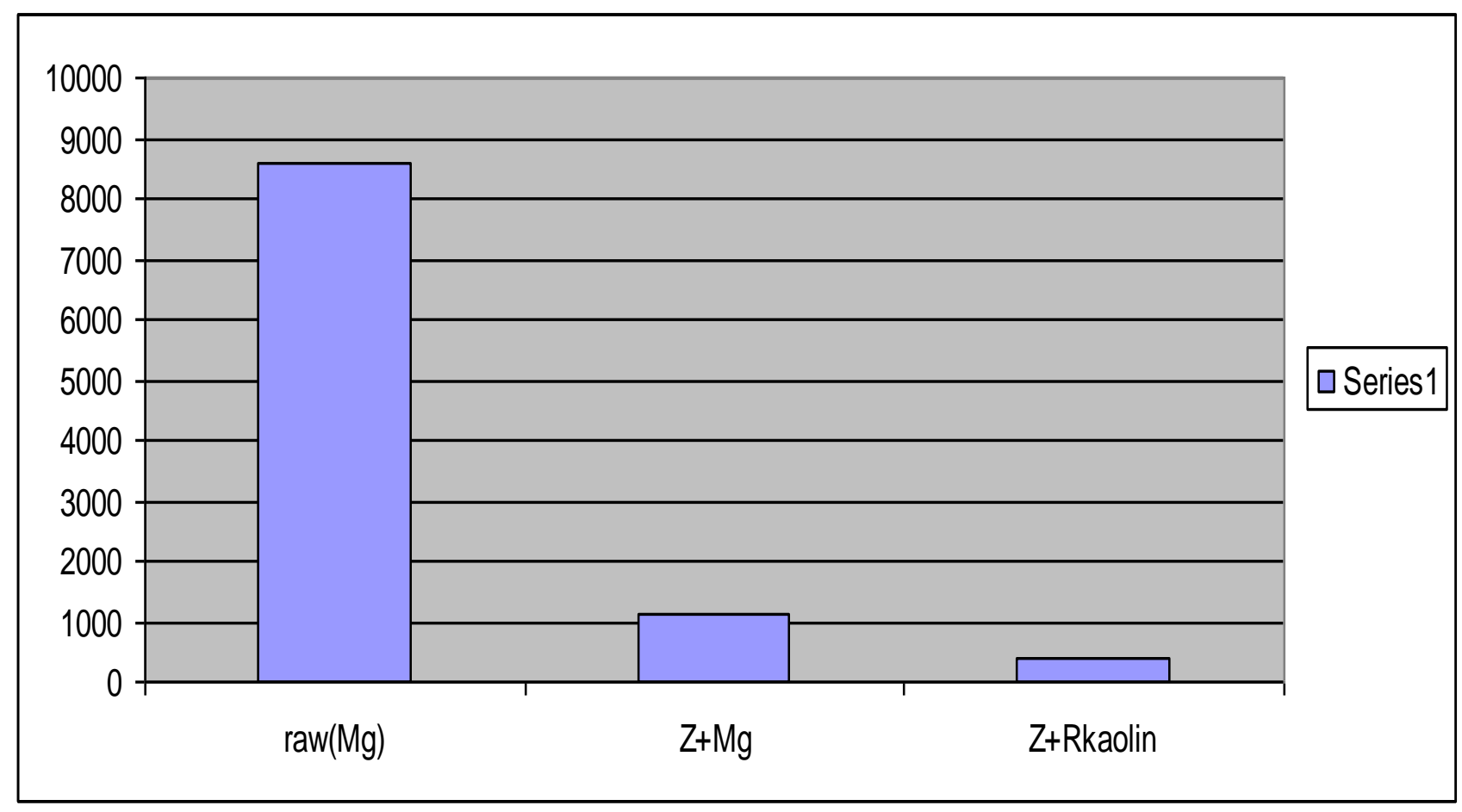

Fig 8 Comparison between Zeolite plus Red kaoline and Zeolite plus Mg for removal of Magnesium.

In this studay magnesium ions were found to be the best ion exchange than calcium ions in sea water by synthetic zeolite compared to natural zeolite 


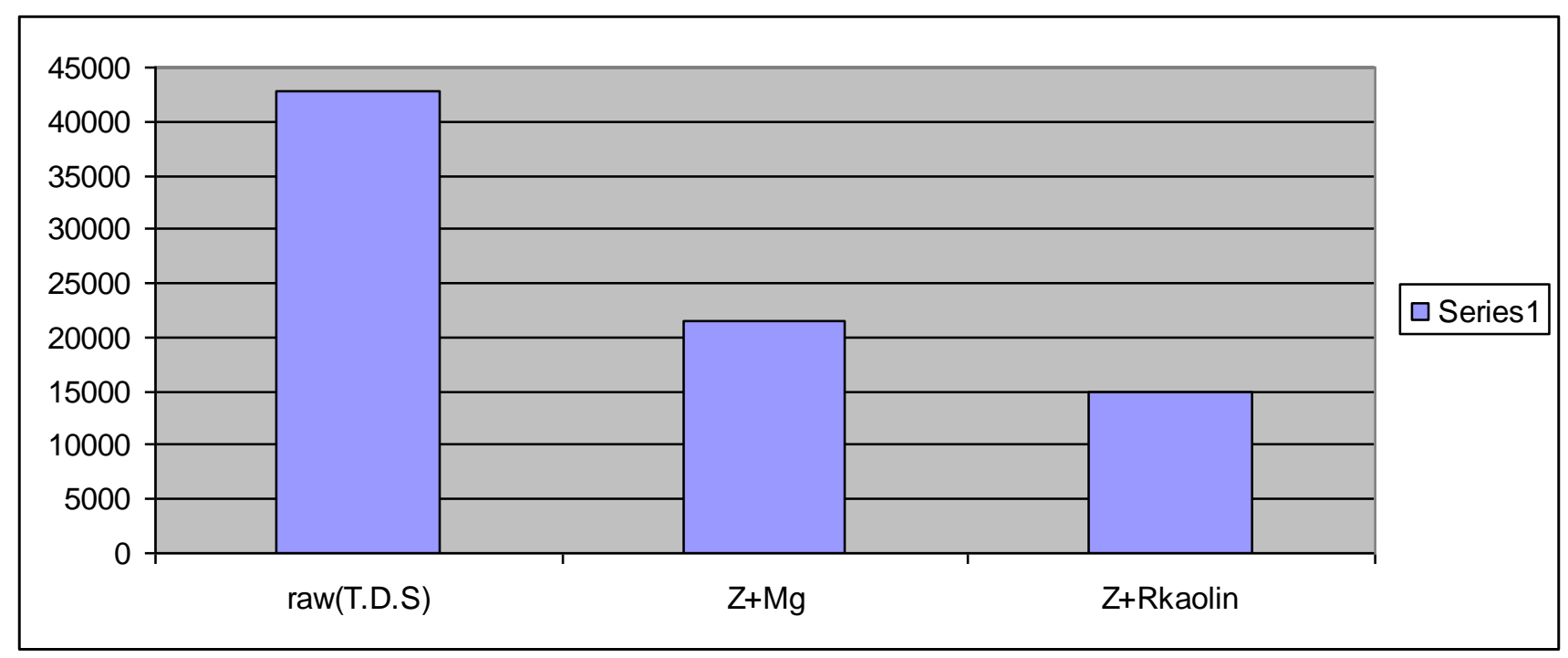

Fig 9 Comparison between Zeolite plus Red Kaoline and Zeolite plus Mg for removal of TDS

\section{CONCLUSION}

Removal of hardness $(\mathrm{Ca}+2$ and $\mathrm{Mg}+2)$ from red sea water was possible using natural zeolite, clay and synthetic zeolites which was prepared from (Kfledspar, clay, Trona, and trace element).I found that synthetic zeolite was the best than clay and retrial zeolite.Also i found that the type of zeolie Albite was the best one to remove the hardness then the type which was $\mathrm{Mg}$ was added to it's good to remove hardness.

In this study magnesium ions were found to be the best ion exchange than calcium ions in sea water by synthetic zeolite compared to natural zeolite. Synthetic Zeolite was synthized by natural substance and there was no contamination and pollution in the environment when synthetic zeolite was used.

\section{REFERENCES}

Assembly of Life Sciences (U.S). "Drinking water and health". National Academy of Sciences (1977).

Bibudhendra Fiarkar, PP.22,29. Heavy Metals in the Environment, The Hospital for Sick Children and University of Toronto Toronto, Ontario, Canada, (2002).

Brude Velde, PP.. 39,41. Orgin and Mineralogy of Clays. 24 rue Lhomond, Paris France, (1995).

Flanigen, E. M. pp,760- 780. Use of zeolites in detergents. Proceedings of 5th International
Conference on Zeolites. Rees, L. V. C. (Ed.) Heyden, London(1980).

Nagy, J. B., Bodart, P., Hannus, I. and Kiricsi, I. Synthesis, Characterization and use of zeolitic microporous materials. Konya, Z. and Tubak, V. (Eds). DecaGen publishers Ltd, Szeged, Hungary (1998).

Nebergall, W.H,Schmidt, F.C,Holtzclaw,H.F, Qualitative Analysis - 5th Edition College of chemistry , Canada (1976) .

Rouquerol, F., Rouquerol, J., and Sing, K., pp. 355, 358. Adsorption by Powder and Porous Solids Principles, Methology and Applications, (Academic Pres Inc. USA),(1999).

Shahwan, T. pp.8, 18. "Radiochemical and spectroscopic studies of cesium, barium, and cobalt sorption on some natural clays", Ph. D. Thesis, Bilkent University, Ankara, Herlich.Kenneth. (1990), Official methods of analysis . 5th ed. Virginia USA (2000). .

TWAS. Safe drinking water-the need, the problem, solutions and an action plan, Third world academy of sciences, Trieste, Italy (2002).

Van Olphen, H., pp.59.. An Introduction to Clay Colloid Chemistry, 2nd ed.; (Wiley, New York,) (1977).

WHO, pp.133 .Guidelines for drinking water quality. Second Edition, Addendum: Microbiological agents in drinking water. Printed in Malta (2002). 